\title{
Job Satisfaction Versus Absenteeism in Municipalities from Bragança District, Portugal
}

\section{Maria Isabel Barreiro RIBEIRO ${ }^{1}$, António José Gonçalves FERNANDES², Isabel Maria LOPES $^{3}$ And António Pedro Ribeiro FERNANDES ${ }^{4}$}

\author{
${ }^{1,2}$ Centro de Investigação de Montanha (CIMO) - Instituto Politécnico de Bragança, Campus Santa \\ Apolónia, Bragança, Portugal \\ ${ }^{3}$ Unidade de Pesquisa Aplicada em Gestão - Instituto Politécnico de Bragança, Campus de Santa \\ Apolónia, 5300-253 Bragança, Portugal; Centro ALGORITMI da Universidade do Minho, Braga, Portugal \\ ${ }^{4}$ Faculdade de Ciências da Universidade do Porto, Rua do Campo Alegre, Porto, Portugal
}

Correspondence should be addressed to: António FERNANDES; topedro11@gmail.pt

Received date:30 March 2021; Accepted date:2 July 2021; Published date: 27 October 2021

Academic Editor: Pedro Ferreira

Copyright (C) 2021. Maria Isabel Barreiro RIBEIRO, António José Gonçalves FERNANDES, Isabel Maria LOPES And António Pedro Ribeiro FERNANDES. Distributed under Creative Commons Attribution 4.0 International CC-BY 4.0

\begin{abstract}
In Portuguese public administration, the absenteeism rates were $6.8 \%$ in $2017,4.8 \%$ in 2016 , and $4.5 \%$ in 2015 (INE, 2018). Towards such high absenteeism rates, the Portuguese government has set as priorities, in the 2021 State budget (Ministério das Finanças, 2020), the investment in good working conditions and the control of absenteeism in the Public Administration. So, this research aimed to analyze the association between absenteeism and job satisfaction and to verify if the municipality size is a differentiator factor of both absenteeism and job satisfaction. A cross-sectional and quantitative study was carried out based on a sample of 245 workers from 6 municipalities located in the Bragança district located in Northeast Portugal. The data were collected using a questionnaire that was administered from April 2018 to July 2019. The data were analyzed using the IBM SPSS Statistics 26.0. In this context, descriptive statistics was used to perform the univariate analysis, and Chi-square and R-Pearson tests were used in the bivariate analysis. On average, the number of absences from work was 15.4 days at the medium-sized municipality and 13.2 days at the small-sized municipalities. The level of job satisfaction was high among municipal workers. However, the municipality size revealed not to be a differentiator factor of both absenteeism and job satisfaction. Also, no correlation was found between job satisfaction and absenteeism. The main reasons associated with the absence were the need to support the family, natural disease, prolonged illness, demotivation, and/or job dissatisfaction, among others.
\end{abstract}

Keywords: Job satisfaction, Municipality, Absenteeism, Employer size.

Cite this Article as: Maria Isabel Barreiro RIBEIRO, António José Gonçalves FERNANDES, Isabel Maria LOPES And António Pedro Ribeiro FERNANDES (2021)," Job Satisfaction Versus Absenteeism in Municipalities from Bragança District, Portugal", IBIMA Business Review, Vol. 2021 (2021), Article ID 956182, 


\section{Introduction}

Municipalities have the mission to pursue the interests of their populations, which includes the promotion of quality public service. In Portugal, in 2019, 128,094 people worked in the municipalities (SIIAL, 2020) and, in 2017, each worker was absent from work, on average, 5.8 days a year (DGAL, 2018).

In the public administration, the absenteeism rates were $6.8 \%$ in $2017,4.8 \%$ in 2016 , and $4.5 \%$ in 2015 (INE, 2018). Towards such high absenteeism rates and, with a tendency to increase, the Portuguese government has set as priorities, in the 2021 State budget (Ministério das Finanças, 2020), the investment in good working conditions and the control of absenteeism in the Public Administration. For this, the Portuguese government published a law in which recommends to the public services managers to use all legal instruments that allow addressing the different needs expressed by their workers, namely work provision regimes and working hours (Law No. 75B/2020).

Absenteeism involves the absence of a worker from his workplace only when this absence is not foreseen (De Faria, Barboza and Domingos, 2005). The vacation period is not considered absenteeism (Ferreira, Griep, Fonseca and Rotenberg, 2012). Absenteeism may be voluntary or involuntary, short or long term and the absence may or may not be justified (Cordeiro, 2011). Worker absences are costly and disruptive for Public Administration, and the trend has steadily increased over the years (Hassan, Wright and Yukl, 2014). In this context, and given the scarcity of studies developed on absenteeism and job satisfaction in local municipalities, this research aimed to analyze the association between absenteeism and the level of bob satisfaction; and, to verify whether the level of job satisfaction and absenteeism differs taking into account the municipalities size.
To achieve these objectives, data were collected through the administration of a questionnaire to 1273 workers from 6 municipalities (5 small-sized municipalities and 1 medium-sized municipality) from the Bragança district located in the Northeast Portugal. The questionnaire included 4 sections (socioeconomic variables; professional nature variables; absenteeism; and attitudes and values associated with work). The questionnaire was administered between April 2018 and July 2019. At the end of the data collection, 245 valid responses were obtained, with a sampling error of $5.6 \%$.

Later, the data analysis involved the use of the IBM SPSS Statistics version 26.0 software in order to analyze the reliability of the questionnaire with Cronbach's Alpha coefficient; to calculate descriptive statistics (univariate analysis); and, to implement the R-Pearson correlation test and Pearson ChiSquare test (bivariate analysis).

The paper is organized into five sections. The introduction justifies the theme, presents the objectives, refers to the methodology and structure of the paper. The second section refers to the literature review in order to contextualize the theme. The third section describes the methodology used in this research, that is, describes data and methods. The fourth section presents the results of the descriptive and analytical studies. Finally, the fifth section reveals the main conclusions which are discussed in light of the literature; refers to the limitations of the study; and presents future researches.

\section{Literature Review}

Work absenteeism can be defined as a phenomenon of multifactorial etiology (Nunes and Vala, 2002; Sampaio and Santos Baptista, 2019) characterized by unplanned absences from work or non-attendance at scheduled work (Bierla, Huver and Richard, 2013). Davey et al (2009) classify absenteeism as the involuntary absence that 
occurs for reasons that the worker does not control and voluntary absence that occurs when the worker makes the decision not to work.

Absenteeism can be associated with several factors (Sampaio and Santos Baptista, 2019). Kinicki and Fugate (2018) describe work absenteeism as the effect or consequence of the interaction between work-related stress factors and the way the worker faces them. Belita, Mbindyo, and English (2013) classify the factors associated with absenteeism in three thematic categories, namely: (1) workplace/content factor (public or private sector, employer size, employer location, work overload, working conditions, change in work units, among others); (2) personal factors (marital status, gender, age, worker hierarchy level, individual's health status, among others); and, (3) organizational and/or cultural factors (leadership style, expectations of peers and society in general, attendance at medical or other examinations, social events such as weddings and funerals, adverse weather conditions, travel and transportation problems, policies adopted by organizations to reduce absenteeism and overtime costs, simultaneous work in the private sector and in most notorious public sector in health professionals, among others).

García-Prado and Chawla (2006) argue that absenteeism, as well as other opportunistic behaviors, are more frequent in public administration. According to these authors, public workers enjoy remuneration, regardless of their productivity. On the other hand, generally, there is no control system and even if there is, the likelihood of formal sanctions is reduced or null.

Job satisfaction is a factor generally considered to be fundamental to the success of organizations, regardless of the sector of activity or the level of development of the country (Rehman et al, 2013; Waqas et al, 2014). It can be defined as the individual's perception of work, which may have a different meaning from person to person, depending on multiple factors (Murad, Zayed and Mukul, 2013), which is why it is considered a complex concept (Coomber and Barriball 2007; Murad, Zayed and Mukul, 2013). Locke (1976) defines job satisfaction as being an emotional, individual, pleasurable, or positive state resulting from the evaluation of the work or its work experiences. On the other hand, job satisfaction can be defined as an emotional reaction to a work condition. The emotional reaction is positive if the results meet or exceed the workers' expectations. On the contrary, it is negative if, for example, the worker feels not to be treated fairly when compared to other co-workers, or if his work does not have the recognition it deserves (Manzoor et al, 2011).

Murad, Zayed and Mukul (2013) identified as determinants of job satisfaction among bankers, the Status of Work and Security, Management Policy, Compensation, Working Conditions, Decision-making Process and Communication Standard, Supervisor Behavior, Nature of Work, Recognition and Promotion. The study developed by Waqas et al (2014) demonstrated that reward and recognition and the work environment were the factors that most influenced job satisfaction. However, the existence of an association between participation in decision-making and job satisfaction has not been demonstrated. In addition, a positive and strong correlation was identified between job satisfaction and work fidelity. On the other hand, Pauli et al (2017) state that workers can acquire satisfaction by mastering the tasks they have to perform and be recognized for that.

\section{Methodology}

This quantitative and cross-sectional research was based on primary data collected from April 2018 to July 2019 in 6 municipalities from Bragança district (5 small-sized municipalities and 1 mediumsized municipality) located in Northeast Portugal. In 2018, the population/universe of this study consisted of 1273 workers distributed, in decreasing order, as follows: 
369 workers from Bragança municipality, 246 workers from Macedo de Cavaleiros municipality, 180 workers from Miranda do Douro municipality, 165 workers from Carrazeda de Anciães municipality, 165 workers from Vimioso municipality and 148 workers from Vila Flor municipality. A simple probabilistic sample consisting of 245 workers was collected, with a sampling error of $5.6 \%$ (Table 1).

Table 1: Geographical distribution of the Population and Sample

\begin{tabular}{|l|c|c|c|}
\hline \multicolumn{1}{|c|}{ Municipality } & Size & Population, 2018 & Sample \\
\hline Bragança & Medium & 369 & 72 \\
\hline Macedo de Cavaleiros & Small & 246 & 41 \\
\hline Miranda do Douro & Small & 180 & 62 \\
\hline Carrazeda de Anciães & Small & 165 & 18 \\
\hline Vila Flor & Small & 165 & 10 \\
\hline Vimioso & Small & 148 & 42 \\
\hline
\end{tabular}

Source: Own elaboration based on data published by SIIAL (2020) and respondents' answers.

To collect the data, a questionnaire consisting of 4 sections was used. The first section included socioeconomic variables that allowed the characterization of the respondent; the second section included questions of professional nature; the third section comprised questions about absenteeism; ultimately the fourth and preceding section included 14 statements about attitudes and values associated with work that were evaluated through the use of a Likert scale ranging from 1 (not at all important) to 5 (very important).

The data analysis involved the use of the IBM SPSS Statistics version 26.0 software to calculate descriptive statistics, namely, absolute (n) and relative (\%) frequencies for nominal variables, as well as the calculation of measures of central tendency, namely, mean $(\bar{x})$, median and mode; and dispersion measures, specifically, maximum, minimum and standard deviation $(\sigma)$ for ordinal and superior/quantitative variables (Pestana and Gageiro, 2014: Maroco, 2018).

Subsequently, the data analysis involved the implementation of statistical tests at a significance level of $5 \%$. The statistical decision rule is to reject the null hypothesis $\left(\mathrm{H}_{0}\right)$ when the probability of significance (Sig.) $\leq$ level of significance. The probability of significance is the lower value of the level of significance for which the null hypothesis can be rejected. The level of significance corresponds to the Type I Error, that is, to reject the null hypothesis when this is true (Maroco, 2018).

To analyze the reliability of the questionnaire, the Cronbach's Alpha coefficient $(\alpha)$ was used. The coefficient value must be positive and can vary between 0 and 1 . Values greater than 0.9 mean that the internal consistency is very good; between 0.8 and 0.9 is good; between 0.7 and 0.8 is reasonable; between 0.6 and 0.7 is weak; and values below 0.6 are not admissible (Nunnally and Bernstein, 1994).

The R-Pearson test was used in the bivariate analysis to study the correlation between variables. This test allows calculating of the " $r$ " correlation coefficient that varies between -1 (perfect negative or perfect inverse correlation) and 1 (perfect direct or perfect positive correlation). Values close to zero indicate a weak correlation and values close to 1 indicate a strong correlation (Pestana and Gageiro, 2014). The R-Pearson correlation test allows to test the following hypotheses:

- $\mathrm{H}_{01}$ : The characteristics of the nature of the work are independent of the workers' attitudes, values and objectives 
in relation to the work. versus

- $\mathrm{H}_{11}$ : The characteristics of the nature of the work depend on the workers' attitudes, values and objectives in relation to the work.

The Pearson Chi-Square test was used to compare proportions considering the municipality's size. It was possible to use this test because the practical rule of the test was verified, that is, the sample size was superior or equal to 20 and the expected frequencies were superior or equal to 5 in at least $80 \%$ of the cells of the contingency table (Maroco, 2018). This test allows testing the following hypotheses:

- $\mathrm{H}_{02}$ : The proportion of workers who were absent from work in the last 12 months before the administration of the questionnaire is the same regardless of the municipalities size. versus

- $\mathrm{H}_{12}$ : The proportion of workers who have been absent from work in the past 12 months before the administration of the questionnaire is higher in medium-sized municipalities compared to small-sized municipalities.

- H03: The proportion of workers satisfied with their work is the same regardless of the municipalities size. versus

- $\mathrm{H}_{13}$ : The proportion of workers satisfied with their work is higher in small-sized municipalities compared to mediumsized municipalities.
- $\mathrm{H}_{04}$ : The proportion of workers with absenteeism is independent of the level of job satisfaction.

versus

- $\mathrm{H}_{14}$ : The proportion of workers with absenteeism is higher when there is a higher proportion of workers dissatisfied with their work.

This study was authorized by the mayors of the municipalities that agreed to be part of this study. The anonymity of the participants and the confidentiality of data were guaranteed to all participants.

\section{Results}

The sample consisted of workers aged between 25 and 68 years old. The average age was 48 years old $(\sigma=9.4)$. As can be seen in Table 2, 70.6\% of workers worked at a small-sized municipality and the, remaining workers worked at a medium-sized municipality. Most respondents were female $(56.3 \%)$, married, or lived in cohabitation (73.9\%) in households with 3 or more people $(61.6 \%)$ that include, at least, one minor or dependent (56.3\%) and had educational qualifications at the level of the secondary education $(36.7 \%)$ or higher education $(42.4 \%)$. With regard to their professional situation, most were permanent workers $(71.8 \%)$, in the professional category of operations assistant $(25.7 \% \%)$ or technical assistant $(31.0 \%)$. The length of service ranged from 6 months to 48 years, with an average of 20 years $(\sigma=10.6)$. 
Table 2: Sociodemographic and professional characterization of workers $(n=245)$

\begin{tabular}{|c|c|c|c|}
\hline \multirow{2}{*}{ Variables } & \multirow{2}{*}{ Categories } & \multicolumn{2}{|c|}{ Frequencies } \\
\hline & & $\mathbf{n}$ & $\%$ \\
\hline \multirow{2}{*}{$\begin{array}{l}\text { Municipality } \\
\text { size }\end{array}$} & Small & 173 & 70.6 \\
\hline & Medium & 72 & 29.4 \\
\hline \multirow{3}{*}{ Gender } & Male & 105 & 42.9 \\
\hline & Female & 138 & 56.3 \\
\hline & Missing & 2 & 0.8 \\
\hline \multirow{4}{*}{ Marital status } & Single & 42 & 17.1 \\
\hline & Married/cohabitation & 181 & 73.9 \\
\hline & Widow & 6 & 2.4 \\
\hline & Divorced/separated & 16 & 6.5 \\
\hline \multirow{6}{*}{$\begin{array}{l}\text { Educational } \\
\text { qualifications }\end{array}$} & $1^{\text {st }}$ Cycle (4 years of schooling) & 17 & 6.9 \\
\hline & $2^{\text {nd }}$ Cycle (6 years of schooling) & 7 & 2.9 \\
\hline & $3^{\text {rd }}$ Cycle ( 9 years of schooling) & 25 & 10.2 \\
\hline & Secondary or equivalent (12 years of schooling) & 90 & 36.7 \\
\hline & Higher education & 104 & 42.4 \\
\hline & Missing & 2 & 0.8 \\
\hline \multirow{5}{*}{ Family unit } & 1 person & 38 & 15.5 \\
\hline & 2 people & 53 & 21.6 \\
\hline & 3 people & 74 & 30.2 \\
\hline & 4 or more people & 77 & 31.4 \\
\hline & Missing & 3 & 1.2 \\
\hline \multirow{6}{*}{$\begin{array}{l}\text { Family unit } \\
\text { (dependents) }\end{array}$} & None & 98 & 40.0 \\
\hline & 1 person & 75 & 30.6 \\
\hline & 2 people & 63 & 25.7 \\
\hline & 3 people & 5 & 2.0 \\
\hline & 5 people & 1 & 0.4 \\
\hline & Missing & 3 & 1.2 \\
\hline \multirow{7}{*}{ Type of contract } & Permanent & 176 & 71.8 \\
\hline & Trial period & 28 & 11.4 \\
\hline & Uncertain-term & 10 & 4.1 \\
\hline & Fixed-term & 11 & 4.5 \\
\hline & Service commission & 8 & 3.3 \\
\hline & Other & 7 & 2.9 \\
\hline & Missing & 5 & 2.0 \\
\hline \multirow{8}{*}{$\begin{array}{l}\text { Professional } \\
\text { category }\end{array}$} & Operations assistant & 63 & 25.7 \\
\hline & Technical assistant & 76 & 31.0 \\
\hline & Advanced technician & 64 & 26.1 \\
\hline & Technical coordinator & 1 & 0.4 \\
\hline & Head of unit & 1 & 0.4 \\
\hline & Head of division & 8 & 3.3 \\
\hline & Head of department & 1 & 0.4 \\
\hline & Head of the presidency support and international relations & 1 & 0.4 \\
\hline
\end{tabular}

Maria Isabel Barreiro RIBEIRO, António José Gonçalves FERNANDES, Isabel Maria LOPES And António Pedro Ribeiro FERNANDES, IBIMA Business Review, DOI: 10.5171/2021.956182 


\begin{tabular}{|l|l|c|c|}
\hline & office & & \\
\cline { 2 - 4 } & City councilor & 1 & 0.4 \\
\cline { 2 - 4 } & Other & 29 & 11.8 \\
\hline
\end{tabular}

As shown in Figure 1, regardless of the municipality size, the reasons given as a justification for the absence of the worker were: support for family members (41.1\%), natural disease $(27.4 \%)$, prolonged illness (10.5\%), demotivation and/or job dissatisfaction (2.1\%), among others
(16.8\%), namely, civic activities, medical consultations and hospitalization (surgery), compliance with court orders, risky pregnancies and maternity, personal reasons and exemptions for tests by a workerstudent.

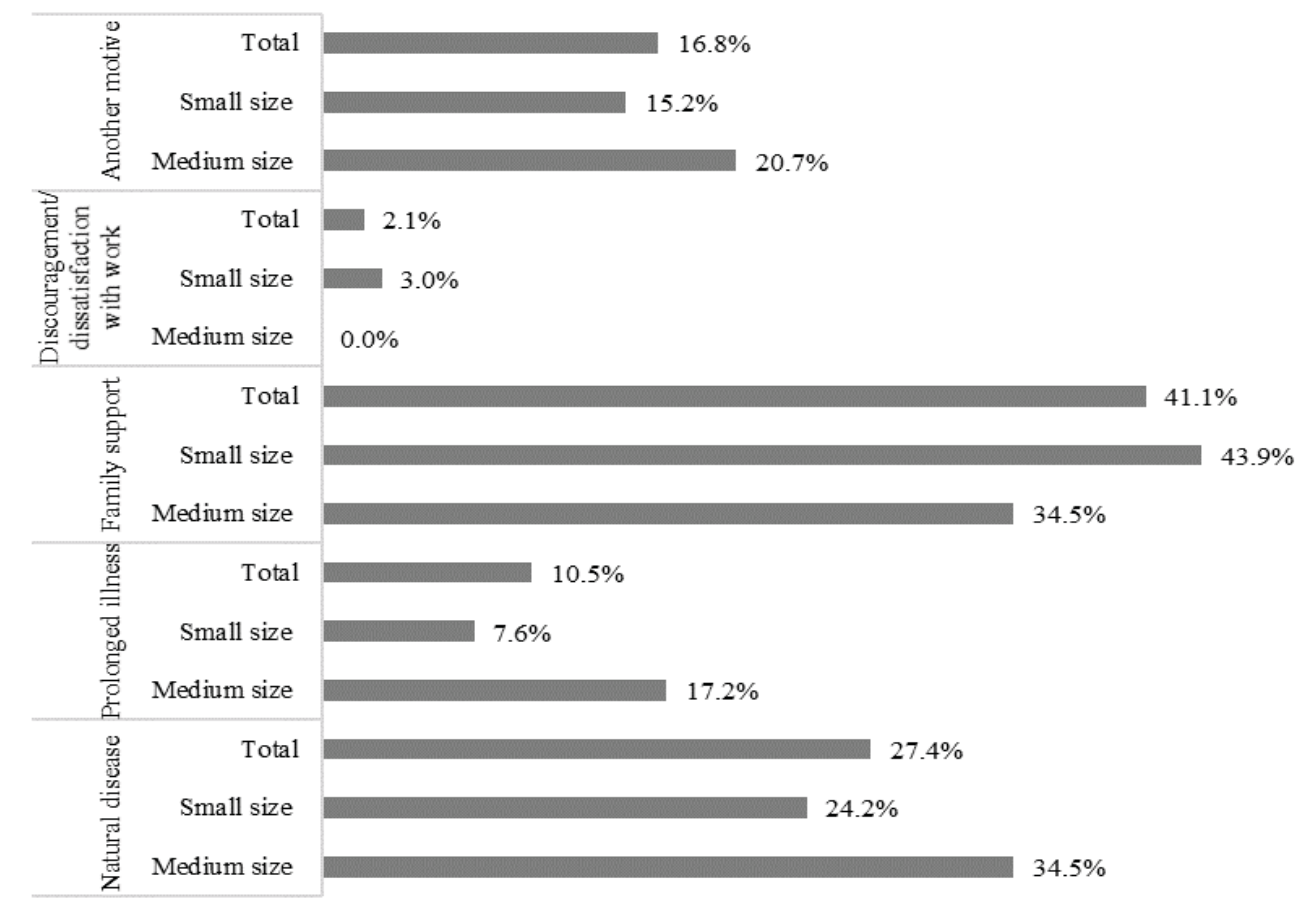

Fig 1. Reasons that justified absenteeism considering the municipality size

As shown in Figure 2, in the last 12 months before the administration of the questionnaire, a significant part of the workers (40.8\%) were absent from their workplace. The number of absences ranged from 1 to 150 days and the average number of absences was about 15 days, although there was great dispersion in the responses obtained $(\sigma=24.5$ days $)$. The median and mode were 5 and 2 days, respectively. 


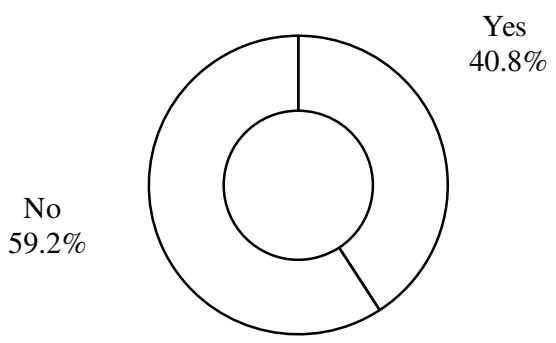

Fig 2. Absenteeism in the last 12 months before the administration of the questionnaire

The reliability analysis of the questionnaire revealed a good internal consistency for the 7 items that constitute the variable "characteristics related to the nature of the work" (Table 3) since $\alpha=0.874$ for all municipalities, $\alpha=0.878$ for the small-sized municipalities and $\alpha=0.866$ for the mediumsized municipality). Also, the reliability analysis for the 7 items that integrated the variable "workers' attitudes, values and objectives in relation to work" (Table 4) revealed a good internal consistency $(\alpha=$ 0.763 for all municipalities, $\alpha=0.762$ for the small-sized municipalities and $\alpha=0.771$ for the medium-sized municipality). Regarding the characteristics associated with the nature of the work, the "relationship with coworkers" stood out in the first three positions, regardless of the municipality size $(\bar{x}=4.46 ; \sigma=0.743)$, the "communication with hierarchical superiors" $(\bar{x}=4.36 ; \sigma=$ 0.786) and, in an identical position, the "adequacy of working hours" $(\bar{x}=4.16 ; \sigma=$ 0.853 ), as well as the "conditions of work facilities" ( $\bar{x}=4.16 ; \sigma=0.855)$. The items that occupied the first two positions remained in the same position in small and medium-sized municipalities. However, in the third position, for workers who worked at small municipalities, the "adequacy of working hours" stood out as the most important $(\bar{x}=4.16 ; \sigma=0.821)$ while for workers who worked at the medium-sized municipality, the "degree of autonomy at work" was more important $(\bar{x}=4.25 ; \sigma=$ 0.687), as shown in Table 3.

Table 3: Mean $(\overline{\mathrm{x}})$, standard deviation $(\sigma)$ and Cronbach's Alpha $(\alpha)$ of the characteristics related with the nature of the work considering the municipality size

\begin{tabular}{|c|c|c|c|c|c|c|c|c|c|}
\hline \multirow[t]{3}{*}{ Items } & \multicolumn{9}{|c|}{ Municipalities } \\
\hline & \multicolumn{3}{|c|}{ Medium-size } & \multicolumn{3}{|c|}{ Small-size } & \multicolumn{3}{|c|}{ All } \\
\hline & $\overline{\bar{x}}$ & $\sigma$ & Rank & $\bar{x}$ & $\sigma$ & Rank & $\overline{\bar{x}}$ & $\sigma$ & Rank \\
\hline Varied and attractive tasks & 4.06 & $\begin{array}{c}0.76 \\
7\end{array}$ & 6 & 4.06 & $\begin{array}{c}0.90 \\
3\end{array}$ & 6 & 4.06 & $\begin{array}{c}0.86 \\
3\end{array}$ & 5 \\
\hline Degree of autonomy & 4.25 & $\begin{array}{c}0.68 \\
7\end{array}$ & 3 & 4.08 & $\begin{array}{c}0.82 \\
1\end{array}$ & 5 & 4.13 & $\begin{array}{c}0.78 \\
6\end{array}$ & 4 \\
\hline Participation in decisions & 3.93 & $\begin{array}{c}0.95 \\
4\end{array}$ & 7 & 3.95 & $\begin{array}{c}0.97 \\
7\end{array}$ & 7 & 3.95 & $\begin{array}{c}0.96 \\
8\end{array}$ & \\
\hline $\begin{array}{ll}\text { Communication } & \text { with } \\
\text { hierarchical superiors } & \end{array}$ & 4.29 & $\begin{array}{c}0.75 \\
9\end{array}$ & 2 & 4.36 & $\begin{array}{c}0.84 \\
5\end{array}$ & 2 & 4.34 & $\begin{array}{c}0.81 \\
9\end{array}$ & 2 \\
\hline $\begin{array}{l}\text { Relationship with } \\
\text { workers }\end{array}$ & 4.36 & $\begin{array}{c}0.71 \\
8\end{array}$ & 1 & 4.50 & $\begin{array}{c}0.75 \\
1\end{array}$ & 1 & 4.46 & $\begin{array}{c}0.74 \\
3\end{array}$ & 1 \\
\hline
\end{tabular}

Maria Isabel Barreiro RIBEIRO, António José Gonçalves FERNANDES, Isabel Maria LOPES And António Pedro Ribeiro FERNANDES, IBIMA Business Review, DOI: 10.5171/2021.956182 


\begin{tabular}{|c|c|c|c|c|c|c|c|c|c|}
\hline Adequacy of working hours & 4.18 & $\begin{array}{c}0.92 \\
4\end{array}$ & 5 & 4.16 & $\begin{array}{c}0.82 \\
1\end{array}$ & 3 & 4.16 & $\begin{array}{c}0.85 \\
3\end{array}$ & 3 \\
\hline $\begin{array}{l}\text { Conditions of } \\
\text { facilities }\end{array}$ workplace & 4.22 & $\begin{array}{c}0.84 \\
3\end{array}$ & 4 & 4.13 & $\begin{array}{c}0.86 \\
1\end{array}$ & 4 & 4.16 & $\begin{array}{c}0.85 \\
5\end{array}$ & 3 \\
\hline Cronbach's Alpha ( $\alpha)$ & \multicolumn{3}{|c|}{0.866} & \multicolumn{3}{|c|}{0.878} & \multicolumn{3}{|c|}{0.874} \\
\hline
\end{tabular}

Regarding the workers' attitudes, values and objectives in relation to work, regardless of the municipalities size, in the first two positions, with the highest levels, are the "ability to respond to work requirements" $(\bar{x}$ $=4.33 ; \sigma=0.781)$ and "job satisfaction" ( $\bar{x}=$ 4.21; $\sigma=0.971)$. The items that occupied the first two positions maintained the same position in small municipalities. However, at the medium-sized municipality, the second position was occupied by the item "continue working at the same place" $(\bar{x}=4.04 ; \sigma=$ 0.993), as shown in Table 4.

Table 4: Mean $(\overline{\mathbf{x}})$, standard deviation $(\sigma)$ and Cronbach's Alpha $(\alpha)$ of the workers' attitudes, values and objectives in relation to work considering the municipality size

\begin{tabular}{|c|c|c|c|c|c|c|c|c|c|}
\hline \multirow[t]{3}{*}{ Items } & \multicolumn{9}{|c|}{ Municipalities } \\
\hline & \multicolumn{3}{|c|}{ Medium-size } & \multicolumn{3}{|c|}{ Small-size } & \multicolumn{3}{|c|}{ All } \\
\hline & $\overline{\bar{x}}$ & $\sigma$ & Rank & $\bar{x}$ & $\sigma$ & Rank & $\bar{x}$ & $\sigma$ & Rank \\
\hline Job satisfaction & 4.03 & 0.921 & 3 & 4.29 & 0.941 & 2 & 4.21 & 0.971 & 2 \\
\hline $\begin{array}{l}\text { Expectations in relation } \\
\text { to work }\end{array}$ & 4.03 & 0.934 & 4 & 4.12 & 0.927 & 3 & 4.09 & 0.959 & 3 \\
\hline $\begin{array}{l}\text { Ability to respond to } \\
\text { work requirements }\end{array}$ & 4.31 & 0.762 & 1 & 4.35 & 0.791 & 1 & 4.33 & 0.781 & 1 \\
\hline Do another work & 3.72 & 0.903 & 7 & 3.36 & 0.905 & 7 & 3.47 & 0.955 & 7 \\
\hline $\begin{array}{l}\text { Motivation and } \\
\text { satisfaction with the } \\
\text { municipality }\end{array}$ & 4.01 & 0.955 & 5 & 3.87 & 0.907 & 6 & 3.91 & 1.091 & 5 \\
\hline $\begin{array}{l}\text { Possibility to evolve and } \\
\text { be promoted }\end{array}$ & 3.90 & 0.915 & 6 & 3.91 & 0.991 & 5 & 3.91 & 1.096 & 6 \\
\hline $\begin{array}{l}\text { Continue working at the } \\
\text { same place }\end{array}$ & 4.04 & 0.993 & 2 & 4.04 & 0.926 & 4 & 4.04 & 0.978 & 4 \\
\hline Cronbach's Alpha $(\alpha)$ & \multicolumn{3}{|c|}{0.771} & \multicolumn{3}{|c|}{0.762} & \multicolumn{3}{|c|}{0.763} \\
\hline
\end{tabular}

Taking into account the results of the ChiSquare test, there were no statistically significant differences in the proportion of workers who were absent from work in the last 12 months before the administration of the questionnaire, taking into account the municipality size (Sig. $=0.912$ ). The same result was obtained taking into account the level of job satisfaction (Sig. $=0.449$ ). This means that the number of workers who were absent from work, as well as the number of workers satisfied with their work, is statically the same in medium and smallsized municipalities (Table 5). 
Table 5: Absenteeism and level of job satisfaction considering the municipality size

\begin{tabular}{|c|c|c|c|c|c|c|c|c|c|c|c|c|}
\hline \multirow[t]{3}{*}{ Municipalities } & \multicolumn{5}{|c|}{ Absenteeism } & \multicolumn{7}{|c|}{ Level of job satisfaction } \\
\hline & \multicolumn{2}{|c|}{ Yes } & \multicolumn{2}{|c|}{ No } & \multirow[t]{2}{*}{ Sig. } & \multicolumn{2}{|c|}{ Low } & \multicolumn{2}{|c|}{ Moderate } & \multicolumn{2}{|c|}{ High } & \multirow[t]{2}{*}{ Sig. } \\
\hline & $\bar{n}$ & $\%$ & $\mathbf{n}$ & $\%$ & & $\mathbf{n}$ & $\%$ & $\bar{n}$ & $\%$ & $\bar{n}$ & $\%$ & \\
\hline Medium-size & 29 & 40.3 & 43 & $\overline{59.7}$ & \multirow[t]{2}{*}{0.912} & 6 & 8.3 & 9 & $\overline{12.5}$ & 57 & 79.2 & \multirow[t]{2}{*}{0.449} \\
\hline Small-size & 71 & 41.0 & 102 & $\overline{59.0}$ & & 7 & 4.2 & 20 & 12.0 & $\overline{139}$ & 83.7 & \\
\hline
\end{tabular}

On the other hand, the results showed that both at small and medium-sized municipalities, the number of workers who were absent from their workplace is the same considering the level of job satisfaction (Sig. > 0.05). In other words, absenteeism is not associated with the level of job satisfaction (Table 6).

Table 6: Absenteeism and job satisfaction considering the municipality size

\begin{tabular}{|c|c|c|c|c|c|c|c|c|}
\hline \multirow[t]{3}{*}{ Municipalities } & \multirow[t]{3}{*}{ Absenteeism } & \multicolumn{6}{|c|}{ Level of job satisfaction } & \multirow[t]{3}{*}{ Sig. } \\
\hline & & \multicolumn{2}{|c|}{ Low } & \multicolumn{2}{|c|}{ Moderate } & \multicolumn{2}{|c|}{ High } & \\
\hline & & $\mathbf{n}$ & $\%$ & $\mathbf{n}$ & $\%$ & $\bar{n}$ & $\%$ & \\
\hline \multirow[t]{2}{*}{ Small-size } & Yes & 4 & 8.3 & 4 & 13.8 & 21 & 72.4 & \multirow[t]{2}{*}{0.339} \\
\hline & No & 2 & 4.7 & 5 & 11.6 & 36 & 83.7 & \\
\hline \multirow[t]{2}{*}{ Medium-size } & Yes & 2 & 2.9 & 7 & 10.3 & 59 & 86.8 & \multirow[t]{2}{*}{0.670} \\
\hline & No & 5 & 5.1 & $\overline{13}$ & 13.3 & $\overline{80}$ & 81.6 & \\
\hline
\end{tabular}

The results of the R-Pearson test proved that there are statistically significant, positive and moderate correlations between the "characteristics related with the nature of the work" and "the workers' attitudes, values and objectives in relation to the work." The positive and moderate correlation was found between the items "varied and attractive tasks" and "degree of autonomy" ( $r=0.620$; Sig. $=0.000)$, "participation in decisions" and "communication with hierarchical superiors" $(\mathrm{r}=$ 0.619; Sig. = 0. 000), "communication with hierarchical superiors" and "conditions of the workplace facilities" ( $r=0.607$; Sig. = 0.000 ), as shown in Table 7.

Job satisfaction showed correlations that ranged from moderate to high with the items "expectations in relation to work" ( $\mathrm{r}=0.767$; Sig. $=0.000)$, "motivation and satisfaction with the municipality" $(\mathrm{r}=0.629$; Sig. $=$ 0.000), "communication with hierarchical superiors" $(\mathrm{r}=0.572 ;$ Sig. $=0.000)$, "conditions of the workplace facilities" ( $\mathrm{r}=$ 0.558; Sig. $=0.000)$, "varied and attractive tasks" ( $r=0.534$; Sig. = 0.000), "possibility to evolve and be promoted" ( $\mathrm{r}=0.528$; Sig. = $0.000)$, "adequacy and flexible working hours" ( $r=0.513$; Sig. = 0.000), "participation in decisions" ( $r=0.497$; Sig. $=0.000)$, "ability to respond to work requirements" ( $r=0.465$; Sig. $=0.000)$, "relationship with co-workers" $(r=0.452$; Sig. = 0.000), "continue working at the same place" ( $r=0.449$; Sig. $=0.000)$ and "degree of autonomy" ( $r=.404$; Sig. $=0.000)$. On the other hand, there was no evidence of a statistically significant correlation between job satisfaction and the item "do another work" ( $r=-0.089$; Sig. $=0.188$ ), as shown in Table 7. 
Table 7: Correlation between the characteristics relates with the nature of the work and the worker's attitudes, values and

\begin{tabular}{|c|c|c|c|c|c|c|c|c|c|c|c|c|c|c|c|}
\hline Items & \begin{tabular}{|l|} 
Statistics \\
\end{tabular} & (1) & (2) & (3) & (4) & (5) & (6) & (7) & (8) & (9) & (10) & (11) & (12) & (13) & (14) \\
\hline \multirow{2}{*}{$\begin{array}{l}1 . \\
\text { satisfaction }\end{array}$} & $\mathrm{r}$ & 1.000 & & & & & & & & & & & & & \\
\hline & Sig. & & & & & & & & & & & & & & \\
\hline \multirow{2}{*}{$\begin{array}{l}\text { 2. Varied and } \\
\text { attractive tasks }\end{array}$} & $\mathrm{r}$ & $0.534^{* *}$ & 1.000 & & & & & & & & & & & & \\
\hline & Sig. & 0.000 & & & & & & & & & & & & & \\
\hline \multirow{2}{*}{\begin{tabular}{|l|l|}
$3 . \quad$ Degree of \\
autonomy
\end{tabular}} & $\mathrm{r}$ & $0.404^{* *}$ & $0.620^{* *}$ & 1.000 & & & & & & & & & & & \\
\hline & Sig. & 0.000 & 0.000 & & & & & & & & & & & & \\
\hline \multirow{2}{*}{$\begin{array}{l}\text { 4. Participation } \\
\text { in decisions }\end{array}$} & $\mathrm{r}$ & $0.497^{* *}$ & $0.572^{* *}$ & $0.552^{* *}$ & 1.000 & & & & & & & & & & \\
\hline & Sig. & 0.000 & 0.000 & \begin{tabular}{|l|}
0.000 \\
\end{tabular} & & & & & & & & & & & \\
\hline \multirow{2}{*}{$\begin{array}{l}5 . \\
\text { Communication } \\
\text { with } \\
\text { hierarchical } \\
\text { superiors } \\
\end{array}$} & $\mathrm{r}$ & $0.572^{* *}$ & $0.546^{* *}$ & $0.506^{* *}$ & $0.619^{* *}$ & 1.000 & & & & & & & & & \\
\hline & Sig. & 0.000 & 0.000 & 0.000 & 0.000 & & & & & & & & & & \\
\hline \multirow{2}{*}{$\begin{array}{l}\text { 6. Relationship } \\
\text { with co- } \\
\text { workers } \\
\end{array}$} & $\mathrm{r}$ & $0.452^{* *}$ & $0.357^{* *}$ & \begin{tabular}{|l}
$0.337^{* *}$ \\
\end{tabular} & $0.392^{* *}$ & $0.581^{* *}$ & 1.000 & & & & & & & & \\
\hline & Sig. & 0.000 & 0.000 & 0.000 & 0.000 & 0.000 & & & & & & & & & \\
\hline \multirow{2}{*}{$\begin{array}{l}\text { 7. Adequacy of } \\
\text { working hours }\end{array}$} & $\mathrm{r}$ & $0.513^{* *}$ & $0.368^{* *}$ & $0.364^{* *}$ & $0.486^{* *}$ & $0.553^{* *}$ & $0.432^{* *}$ & 1.000 & & & & & & & \\
\hline & Sig. & 0.000 & 0.000 & \begin{tabular}{|l|}
0.000 \\
\end{tabular} & 0.000 & 0.000 & 0.000 & & & & & & & & \\
\hline \multirow{2}{*}{$\begin{array}{l}\text { 8. Conditions of } \\
\text { the workplace } \\
\text { facilities }\end{array}$} & $\mathrm{r}$ & $0.558^{* *}$ & $0.575^{* *}$ & $0.469^{* *}$ & $0.524^{* *}$ & $0.607^{* *}$ & $0.540^{* *}$ & $0.432^{* *}$ & 1.000 & & & & & & \\
\hline & Sig. & 0.000 & 0.001 & 0.000 & 0.000 & 0.000 & 0.000 & 0.000 & & & & & & & \\
\hline \multirow{2}{*}{$\begin{array}{l}\text { 9. Expectations } \\
\text { in relation to } \\
\text { work }\end{array}$} & $\mathrm{r}$ & $0.767^{* *}$ & $0.496^{* *}$ & $0.416^{* *}$ & $0.478^{* *}$ & $0.556^{* *}$ & $0.453^{* *}$ & $0.540^{* *}$ & $0.561^{* *}$ & 1.000 & & & & & \\
\hline & Sig. & 0.000 & 0.000 & 0.000 & 0.000 & 0.000 & 0.000 & 0.000 & 0.000 & & & & & & \\
\hline \multirow{2}{*}{\begin{tabular}{ll|}
10. Ability & to \\
respond & to \\
work & \\
requirements \\
\end{tabular}} & $\mathrm{r}$ & $0.465^{* *}$ & $0.411^{* *}$ & $0.335^{* *}$ & $0.326^{* *}$ & $0.440^{* *}$ & $0.427^{* *}$ & $0.453^{* *}$ & $0.454^{* *}$ & $0.521^{* *}$ & 1.000 & & & & \\
\hline & Sig. & 0.000 & 0.000 & 0.000 & 0.000 & 0.000 & 0.000 & 0.000 & 0.000 & 0.000 & & & & & \\
\hline \multirow{2}{*}{$\begin{array}{l}\text { 11. Do another } \\
\text { work }\end{array}$} & $r$ & \begin{tabular}{|l|}
-0.089 \\
\end{tabular} & $0 .-004$ & 0.073 & 0.015 & $0.092^{*}$ & 0.040 & 0.052 & 0.032 & -0.053 & -0.019 & 1.000 & & & \\
\hline & Sig. & 0.188 & 0.951 & 0.270 & 0.826 & 0.163 & 0.544 & 0.431 & 0.628 & 0.426 & 0.778 & & & & \\
\hline
\end{tabular}

Maria Isabel Barreiro RIBEIRO, António José Gonçalves FERNANDES, Isabel Maria LOPES And António Pedro Ribeiro FERNANDES, IBIMA Business Review, DOI: $10.5171 / 2021.956182$ 


\begin{tabular}{|c|c|c|c|c|c|c|c|c|c|c|c|c|c|c|c|}
\hline \multirow{2}{*}{$\begin{array}{l}\text { 12. Motivation } \\
\text { and satisfaction } \\
\text { with the } \\
\text { municipality }\end{array}$} & $r$ & $0.629^{* *}$ & $0.398^{* *}$ & $0.378^{* *}$ & $0.404^{* *}$ & $0.469^{* *}$ & $0.310^{* *}$ & $0.388^{*}$ & $0.409^{* *}$ & $0.590^{* *}$ & $0.278^{* *}$ & $\begin{array}{c}- \\
0.042 \\
\end{array}$ & 1.000 & & \\
\hline & Sig. & 0.000 & 0.000 & 0.000 & 0.000 & 0.000 & 0.000 & 0.000 & 0.000 & 0.000 & 0.000 & 0.529 & & & \\
\hline \multirow{2}{*}{$\begin{array}{l}\text { 13. Possibility } \\
\text { to evolve and } \\
\text { be promoted }\end{array}$} & $\mathrm{r}$ & $0.528^{* *}$ & $379^{* *}$ & $367^{* *}$ & $0.348^{* *}$ & $0.375^{* *}$ & $0.293^{* *}$ & $0.351^{* *}$ & $0.361^{* *}$ & $0.558^{* *}$ & $0.237^{* *}$ & $\begin{array}{c}- \\
0.003\end{array}$ & $0.535^{* *}$ & & \\
\hline & Sig. & 0.000 & 0.000 & 0.000 & 0.000 & 0.000 & 0.000 & 0.000 & 0.000 & 0.000 & 0.000 & 0.969 & 0.000 & & \\
\hline \multirow{2}{*}{$\begin{array}{l}\text { 14. Continue } \\
\text { working at the } \\
\text { same place }\end{array}$} & $\mathrm{r}$ & $0.449^{* *}$ & $0.285^{* *}$ & $0.313^{* *}$ & $0.307^{* *}$ & $0.287^{* *}$ & $0.245^{* *}$ & $0.340^{* *}$ & $0.282^{* *}$ & $0.477^{* *}$ & $0.238^{* *}$ & $\begin{array}{c}- \\
0.147^{*}\end{array}$ & $0.524^{* *}$ & $0.435^{* *}$ & 1.000 \\
\hline & Sig. & 0.000 & 0.000 & 0.000 & 0.000 & 0.000 & 0.000 & 0.000 & 0.000 & 0.000 & 0.000 & 0.026 & 0.000 & 0.000 & \\
\hline
\end{tabular}

** The correlation is significant at the 0.01 significance level.

* The correlation is significant at the 0.05 significance level.

Maria Isabel Barreiro RIBEIRO, António José Gonçalves FERNANDES, Isabel Maria LOPES And António Pedro Ribeiro FERNANDES, IBIMA Business Review, DOI: $10.5171 / 2021.956182$ 


\section{Conclusion and Discussion}

This quantitative research aimed to analyze the relationship between absenteeism and the level of job satisfaction and to verify whether absenteeism and the level of job satisfaction differ taking into account the municipality size. Data were collected in six Municipalities located in the Bragança district in the Northeast of Portugal. Of these, one was medium-sized, and the remaining five were small-sized municipalities. The random probabilistic sample obtained consisted of 245 workers, of whom $70.7 \%$ were workers from small-sized municipalities and the remaining were workers from the medium-sized municipality. The workers were aged between 25 and 68 years old and were mostly female. From the professional point of view, most were permanent workers at the professional category of operations assistant or technical assistant.

In the last 12 months before the administration of the questionnaire, more than $40.0 \%$ of workers were absent from their workplace $(41.0 \%$ workers from smallsized municipalities and $40.3 \%$ workers from the medium-sized municipality). The number of absences ranged from 1 to 150 days and the average number of absences was about 15 days (15.4 days at the medium-sized municipality and 13.2 days at the small-sized municipalities). However, there were no statistically significant differences in the proportion of workers who were absent from work in the last 12 months before the administration of the questionnaire, taking into account the municipality size.

The main reason associated with the absence of the worker from work was the need to support the family, followed by natural disease, prolonged illness, demotivation and/or job dissatisfaction, among others. Similar results were obtained by Kocakulah et al (2016) and Jong (2018). In Portugal, at the municipalities, the total number of absences from work accounted for 425 days, in 2017, excluding the holidays. Of this total, the most significant number is related to the disease of the worker (178 days of the total days of absence that correspond to $42.0 \%$ ). On average, each worker is absent from work 5.8 days a year. When the distinction between genders is made, it is concluded that, on average, men are absent 3 days a year while women, on average, are absent 7 days a year (DGAL, 2018). Sampaio and Batista (2019) distributed the predictors of absenteeism of public workers in three approaches, namely: (1) Sociodemographic, which includes individual and organizational characteristics as well as the social context; (2) Medical, which involves mental disorders, bullying, among other diseases; and, (3) Work attitudes, namely, effort-reward imbalance, demand-control relation, organizational justice, organizational ethics, work support, affective organizational commitment, work motivation, stress, burnout and psychosomatic complaints. Regarding the first approach, Sampaio and Batista (2019) concluded that women are more absent from work than men, since women traditionally assume responsibilities in relation to home and family. In this sense, the results of the present study proved that many of the absences are essentially to support the family, since the majority of workers were female. The disease (Buzeti, 2020; Jong, 2018; Mudaly and Nkosi, 2015) and family care (Jong, 2018; Vignoli et al, 2016) are considered the main reasons that justify unplanned absences from work.

Workers recorded high levels of job satisfaction. However, the analysis of the results also allows us to concluded that the proportion of workers distributed by the level of job satisfaction is statistically the same in small and medium-sized municipalities. A study developed by Allen (1982) identified employer size as an important determinant of absenteeism. According to the author, the larger the employer, the greater the absenteeism, since the size decreases communication and group cohesion, resulting in less worker satisfaction. On the other hand, the increase 
in size leads to more bureaucracy, which reduces informal controls associated with higher levels of interpersonal interests and greater attachment. Thus, in larger employers, the performance of workers goes, most of the time and more easily, unnoticed.

The results of the present study also showed that job satisfaction and absenteeism were not associated and municipalities size was not a differentiating factor of both job satisfaction and absenteeism. According to Drakopoulos and Grimani (2013) and McShane (1984) there is no universal agreement on the relation between absenteeism and job satisfaction, as it is a complex issue, influenced by multiple factors, both personal and organizational. If, on the one hand, it is believed that absence from work is, in some way, a natural consequence of job dissatisfaction, since job satisfaction has an impact on absenteeism (Steers and Rhodes, 1978; Lokke, 2007; Agapito and Sousa, 2010; Drakopoulos and Grimani, 2011; Stefano, Vergara, Godoy and Freitas, 2014; Thirulogasundaram and Sahu, 2014; Baía and Ramos, 2017; Poongavanam, 2017) there are those who admit the possibility of the inexistence of an apparent association between job satisfaction and absenteeism (Matrunola, 1996; Roncalli and Byrne, 2016, Ribeiro, Lopes and Fernandes, 2019).

The characteristic associated with the nature of work most valued by workers was the "relationship with co-workers", which is consistent with the findings of Baía and Ramos (2017). In addition, there were proven correlations that varied from moderate to high between job satisfaction and the characteristics related to the nature of the work, as well as with the worker's attitudes, values and objectives, namely, with the items "expectations in relation to work", "motivation and satisfaction with the municipality", "communication with hierarchical superiors", "conditions of the workplace facilities", "varied and attractive tasks", "possibility to evolve and be promoted", "adequacy and flexibility of working hours", "participation in decisions", "ability to respond to work requirements", "relationships with co-workers", "continue working at the same place" and "degree of autonomy". Similar results were obtained in the study developed by Baía and Ramos (2017). However, in the research carried out by Waqas et al (2014), the existence of a statistically significant association between participation in decision-making and job satisfaction has not been demonstrated.

The conclusions of this work are based on a simple random sample, which is not representative of the universe studied, So the results cannot be generalized to the population that was the target of this study. However, the conclusions will always be valid for the group of workers analyzed. If the sample size and the geographical area of study increase, the results will be more expressive and more accurate. Another limitation of the study is related to its crosssectional nature and, for that reason, it is a static study. Given the limitations of this research, it is suggested that results should be analyzed with caution, because there are not enough studies, in different contexts, to allow comparisons. Future researches should involve more workers and more municipalities in order to increase the sample size. In addition, a longitudinal study will allow understanding the evolution over time of both absenteeism and job satisfaction.

\section{Acknowledgments}

The authors are grateful to the Foundation for Science and Technology (FCT, Portugal) for financial support by national funds FCT/MCTES to CIMO (UIDB/00690/2020).

\section{References}

- $\quad$ Agapito, S. M. and Sousa, F.C. (2010) 'A influência da satisfação profissional no absentismo laboral,' Revista Portuguesa de Saúde Pública, 28 (2), 132-139.

- Allen, P.T. (1982) 'Size of workforce, morale and absenteeism: are- 
examination,' British Journal of Industrial Relations, 20, 83-100.

- Baía, A. and Ramos, C. (2017) 'Absenteeism: Moibe Municipality Portugal,' International Journal of Business and Management Studies, 6 (2), 335-350.

- Belita, A., Mbindyo, P. and English, M. (2013) 'Absenteeism amongst health workers-developing a typology to support empiric work in low-income countries and characterizing reported associations,' Human Resources for Health, 11 (34), 1-10.

- Bierla I., Huver, B. and Richard, S. (2013) 'New evidence on absenteeism and presenteeism,' The International Journal of Human Resource Management, 24 (7), 1536-1550.

- Buzeti, J. (2020). Association between Field of Work, Years of Service, and Sickness Absenteeism in Public Administration. Organizacija, 53 (1), 5367.

- Coomber, B. and Barriball, K.L. (2007) 'Impact of job satisfaction components on intent to leave and turnover for hospital-based nurses: a review of the research literature,' International Journal of Nursing Studies, 44 (2), 297-314.

- Davey, M.M., Cummings, G., Newburn-Cook, C.V. and Lo, E.A. (2009) 'Predictors of nurse absenteeism in hospitals: a systematic review,' Journal of Nursing Management, 17, 312-330.

- DGAL (Direção Geral das Autarquias Locais (2018), 'Balanço Social 2017,' [Online], [Retrieved March 23, 2021] http://www.portalautarquico.dgal.gov.pt /static-img/2018-04/2018-0413152807 4c65f7f1-2e56-4968-a1af585420fa64e0 \$\$69a7a8ae-8e1a-4d9e9f30-15842995d418\$\$faf69560-d2224100-8276-

2adc07c34bd9\$pt pt file\$\$pt\$1.pdf

- Drakopoulos, S. and Grimani, A. (2011) 'The relationship between absence from work and job satisfaction: Greece and UK comparisons,' Munich
Personal RePEc Archive, 30990.

- Drakopoulos, A.A. and Grimani, K. (2013) 'Injury-related absenteeism and job satisfaction: insights from Greek and UK data,' The International Journal of Human Resource Management, 24 (18), 3496-3511.

- García-Prado, A. and Chawla, M. (2006) 'The impact of hospital management reforms on absenteeism in Costa Rica,' Health Policy and Planning, 21 (2), 91-100.

- Hassan, S., Wright, B. E. and Yukl, G. (2014) 'Does Ethical Leadership Matter in Government? Effects on Organizational Commitment, Absenteeism, and Willingness to Report Ethical Problems,' Public Administration Review, 74 (3), 333-343.

- INE (2017) Balanço Social 2017, Instituto Nacional de Estatística Lisboa.

- Jong, J. (2018) 'The Role of Social Support in the Relationship Between Job Demands and E mployee Attitudes in the Public Sector,' International Journal of Public Sector Management, 31 (6), 672688.

- Kinicki, A. and Fugate, M. (2018) Organizational behavior. A practical, problem-solving approach, McGraw Hill, New York.

- Kocakulah, M.C., Kelley, A., Mitchell, K.M. and Ruggieri, M.P. (2016) 'Absenteeism Problems and Costs: Causes, Effects and Cures,' International Business and Economics Research Journal (IBER), 15 (3), 89-96.

- Locke E.A. (1976) The Nature and Causes of Job Satisfaction, Handbook of industrial and organizational psychology, Dunette M.D. (ed), Rand McNally, Chicago.

- Lokke, A-K., Eskildsen, J. and Jensen, T., (2007) 'Absenteeism in the Nordic Countries,' Employee Relations, 29 (1), 16-29.

- Maroco, J. (2018) Análise Estatística com o SPSS statistics, RportNumber, Pero Pinheiro.

- Matrunola, P. (1996) 'Is there a 
relationship between job satisfaction and absenteeism?,' Journal of Advanced Nursing, 23 (4), 827-834.

- Manzoor, M. U., Usman, M., Naseem, M. A., and Shafiq, M.M. (2011) 'A Study of Job Stress and Job Satisfaction among Universities Faculty in Lahore,' Pakistan Global Journal of Management and Business Research, 11 (9), 1-5.

- McShane, S.L. (1984) 'Job Satisfaction and Absenteeism. A MetaAnalytic Re-examination,' Canadian Journal of Administrative Sciences, 1 (1), 61-77.

- Ministério das Finanças (2020) Orçamento do Estado 2021: Proposta de Lei e Relatório, Ministério das Finanças, Lisboa.

- Mudaly, P. and Nkosi, Z.Z. (2015) 'Factors Influencing Nurse Absenteeism in a General Hospital in Durban, South Africa,' Journal of Nursing Management, 23 (5), 623-31.

- Murad, M.M., Zayed, N. M. and Mukul, A.Z. (2013) 'A Study on Job Satisfaction: Focus on Bankers of Bangladesh,' European Journal of Business and Management, 5, 14-20.

- $\quad$ Nunes, F. and Vala, J. (2002) Cultura organizacional e gestão de recursos humanos, Gestão de recursos humanos: contextos, processos e técnicas, Caetano, A. and Vala, J., (eds). Editora RH, Jisboa.

- Nunnally, J. and Bernstein, I. (1994) Psychometric theory, McGraw-Hill, New York.

- Pauli, J., Tomasi, M., Gallon, S., and Coelho, E. (2017) 'Satisfação, Conflitos e Engajamento no Trabalho para Professores do Ensino Médio,' Revista Pensamento Contemporâneo em Administração, 11 (4), 72-85.

- Pestana, M. and Gageiro, J. (2014) Análise de dados para ciências sociais: a complementaridade do SPSS, Sílabo, Lisboa.

- Poongavanam S. (2017) 'Employee absenteeism-A case study of leather firm in Vellore,' International Journal of Research in Social Sciences, 7 (10), 5-21.

- Rehman, K., Rehman, Z., Saif, N.,
Khan, A.S., Nawaz, A. and Rehman, S. (2013) 'Impacts of Job Satisfaction on Organizational Commitment: A Theoretical Model for Academicians in HEI of Developing Countries like Pakistan,' International Journal of Academic Research in Accounting, Finance and Management Sciences, 3 (1), 80-89.

- $\quad$ Ribeiro, M.I.B., Fernandes, A.J.G. and Lopes, I.M. (2019) 'Absenteeism and Job Satisfaction in a Portuguese Municipality,' The Journal of Organizational Management Studies, 168494.

- Roncalli, S. and Byrne, M. (2016) 'Relationships at work, burnout and job satisfaction: A study on Irish psychologists,' Mental Health Review Journal, 21 (1), 23-36.

- SIIAL (Sistema Integrado de Informação das Autarquias Locais) (2020), 'Trabalhadores municipais de 2010 a 2019,' Portal Autárquico. [Online], [Retrieved March 23, 2021] http://www.portalautarquico.dgal.gov.pt /pt-PT/administracao-local/recursoshumanos/.

- Sampaio, E. and Santos Baptista, J.S. (2019) Absenteeism of public workers Short review, Occupational and Environmental Safety and Health, Arezes P. et al (eds), Springer, Cham.

- Steers, R. and Rhodes, S. (1978) 'Major influences on employee attendance: A process model,' Journal of Applied Psychology, 63, 391-407.

- Stefano, N.M., Vergara, L.G.L., Godoy, L.P. and Freitas, M.C.D. (2014) 'Quality of work life (QWL) and absenteeism index (AI) in a small business,' Latin American Applied Research, 44, (4), 363-367

- Thirulogasundaram, V.P. and Sahu, P.C. (2014) 'Job satisfaction and absenteeism interface in Corporate Sector-A study,' Journal of Humanities and Social Science (IOSR-JHSS), 19, 6468.

- Vignoli, M., Guglielmi, D., Bonfiglioli, R. and Violante, F.S. (2016) 'How Job Demands Affect Absenteeism? The 
Mediating Role of Work-Family Conflict and Exhaustion,' International Archives of Occupational and Environmental Health, 89, (1), 23-31.

- Waqas. A., Bashir. U., Sattar. F., Hafiz Abdullah, M., Hussain, I., Anjum, W.,
Aftab Ali, M.A. and Arshad. R. (2014) 'Factors Influencing Job Satisfaction and Its Impact on Job Loyalty,' International Journal of Learning and Development, 4 (2), 141-161. 